\title{
Dealing with the cultural and financial challenges during death of a loved one and repatriation of the remains: A mission to the wounded
}

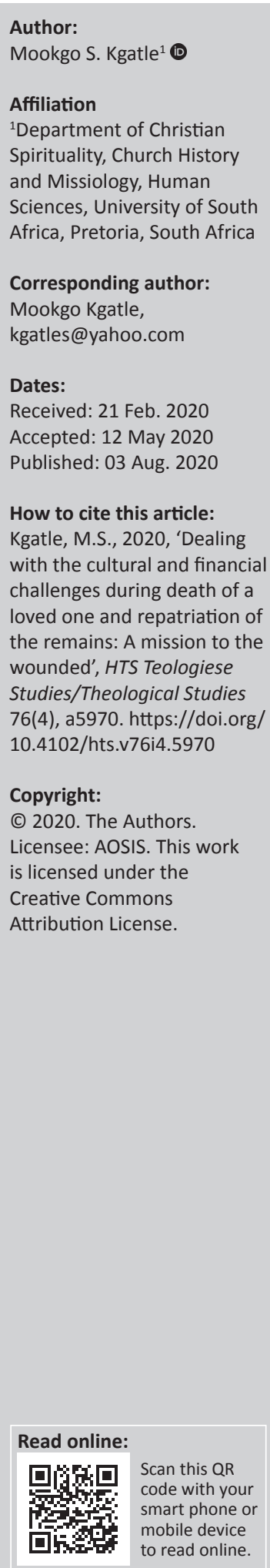

The death of a loved one and the repatriation of the remains have become the double pain experienced by many Zimbabweans in South Africa. The double pain is caused by the cultural demand for burial to be conducted at the home country and the financial demands to do so. While previous studies on mission and theology have addressed the pain of death, only few have looked at the second pain of repatriation. The research gap calls for missiologists to seek ways of addressing the double pain as caused by cultural and financial challenges. By conducting interviews with the Zimbabweans in South Africa, missiological ways of dealing with the double pain are sought through the participant observation method. The proposal is that 'a mission to the wounded' as a theoretical framework within missiology is able to deal with these challenges. In addition, there is a need to embrace alternative burial protocol and rethink cremation as an additional solution to financial challenges.

Contribution: This article revisits a theology of mission by suggesting 'a mission to the wounded' in light of death and repatriation.

Keywords: pain; death; repatriation; cultural anthropology; missiology.

\section{Introduction}

About 3-4 million Zimbabweans have migrated to other countries, given the economic challenges in their own country. This means that a quarter of Zimbabweans are living outside their country. African countries have a fair share of the total number of Zimbabweans living outside their country, at about 2.5 million.

Seventy-five percent of the 2.5 million live in South Africa. This means that South Africa is better placed to study the repatriation of the bodies of Zimbabwean migrants (Makina 2012:365378) because there is a great presence of Zimbabweans in South Africa. However, during the death of a loved one, the Zimbabwean migrants in South Africa go through what this article refers to as 'double pain'. They go through the pain of mourning the loss of their loved one, on the one hand, and the pain of dealing with the repatriation of the body of the deceased, on the other hand.

This is because most Zimbabweans living in other countries like to be buried in Zimbabwe. Rowles and Comeaux (1987:115) opined that the belief one should be buried at "home" among friends and relatives is a human trait finding expression in a diversity of cultures'. According to Félix (2011:158), it is 'the expressed desire of migrants in life to be returned to their community of origin in death'. Nunez and Wheeler (2012) added that some migrants:

$[M]$ ay wish to return home when facing a possibility of their own death in a foreign country to avoid the risk of not being able to return home after death. (p. 214)

In the words of Fontein (2009):

The process of bringing human bodies back to Zimbabwe is done to bring back the spirit of the dead person back to his or her root and ensure that it rests in the right place. (p. 14)

Correspondingly, Fontein sustained that failure to perform these specific rituals to return the spirits of the dead has consequences. In some cases, if a person is not buried in their place of origin, their spirit might come back as bad sign and cause problems within the family. It is 
understood to anger and trouble the spirits and in turn precipitate great personal or family misfortune (Fontein 2009:14). Therefore, to avoid cultural and spiritual problems, families go the extra mile to ensure the repatriation of their loved ones. Although the cultural reasons for repatriating bodies back to Zimbabwe are valid, there is a need to be practical and do a cost-benefit analysis; the money used to transport the body could be used to support the education of the deceased's children.

The cultural and subsequent financial challenges of repatriating the remains of Zimbabwean migrants in South Africa call for a different way of doing mission. Mission to those mourning the loss of their loved ones in their home country cannot be the same as for those mourning outside their home country. Those who mourn away from their country are going through the double pain of death and repatriation of their loved one's remains (challenge) at the same time. By using 'mission to the wounded' as a theoretical framework, the article reimagines the repatriation of bodies back to Zimbabwe by being sensitive to the cultural values of those who insist that their bodies be buried in their home country. Secondly, the article reimagines cremation as a way of dealing with the financial costs involved with the repatriation of dead bodies. Thus, 'mission to the wounded' in this context, according to Kritzinger, refers to the sensitivity that needs to be offered to the community of Zimbabweans in need of help in burying their loved ones. It is not only a commitment to the Christian faith, but also how the Christian faith can be maintained among those who are mourning, on the one hand, as well as facing cultural and financial challenges, on the other hand (Kritzinger 2013:97). Mission has to be done by considering its context (Kgatle 2018:2). Kgatle (2019:63) continues by saying, 'It is not only a redemptive mission but also the mission with social responsibilities to the poor, oppressed, sick, prisoners and the vulnerable in society'.

\section{Methodology}

This article uses the participant observation method with a qualitative research design. This method was used to collect data from Zimbabwean migrants, which were then analysed by the researcher. Participant observation is used in ethnographic studies, especially to understand different cultures in a better way. The method is not only applicable to social sciences, but it can also be used in many other disciplines, particularly Cultural Anthropology, Ethnology, Sociology, Communication Studies, Human Geography and Social Psychology. The main purpose of this method is to gather information within a specific community or group such as a religious group or organisation. In this article, it was used to gather information on the Zimbabwean migrants in South Africa. Therefore, participant observation is known for objectivity in research such that the research conducted is free of judgement, stereotypes and imposition.

The researcher conducted interviews among Zimbabweans living in South Africa. Ten people were interviewed. The participants were selected by looking at families who had experienced repatriation of their loved ones from South Africa. The following five main questions were asked:

- Q1: What is the experience of having to deal with the pain of the death of a fellow congregant?

- Q2: What is the process for repatriating a dead body from South Africa?

- Q3: How does the process of repatriating remains affect the grieving family?

- Q4: What is the relationship between mourning the death of a loved one and the pain of the repatriation of remains?

- Q5: What are the best ways to help migrant families deal with the double pain of death and the repatriation of their loved ones' remains?

Table 1 shows the number of participants, criteria for selection, questions and comments.

\section{The pain of death}

Death is painful on its own; it does not matter if it is the death of a child, someone middle-aged or an elderly person. It does not matter if the cause is natural or accidental. Death does not respect one's economic status, religious affiliation, race, skin colour or ethnicity. Death remains painful. However, death is more painful if one has to deal with the challenges of repatriating the remains, which requires a lot of effort and financial ability. In the words of Connolly et al. (2017:1), 'the death of a family member or friend is a traumatic event. This trauma is intensified in the setting of foreign travel'. During the interview, the participants were asked a question: what is the experience of having to deal with the pain of death of fellow congregant? In answering this question, one of the participants said that it is always a very difficult moment, given that most congregants, especially close relatives, will be looking for guidance and leadership for most of the procedures and processes.

The participants agreed that death is the principal cause of grief and pain experienced by family and friends. However, pain is not only caused by the loss of loved ones but other associated matters. These difficulties can lead people into a loss of hope for the future (Dysvik \& Furnes 2010:163). In addition, the loss of a loved one has the potential to cause a root of bitterness in life, where even small matters cause a person to be angry. Some people even go to the extent of losing their faith during the loss of their loved one. When people are not strong in the Lord, they can easily lose their faith during the death of their loved one because their faith is not grounded. Some mourning families sometime struggle with questions like why did they lose their loved one? Failure to answer such questions leads many to a loss of faith (Marrone 1999:495-519).

\section{The process of repatriation of remains}

Repatriation, according to Connolly et al. (2017:1), is the process whereby 'human remains are transferred from a foreign territory to the native land of the deceased'. 
TABLE 1: The data of participants

Question
Q1: What is the experience of
having to deal with the pain of
death of a fellow congregant?
Q2: What is the process for
repatriating a dead body from
South Africa?
Q5: What are the best ways to
help migrant families deal with
the double pain of death and
the repatriation of their loved
ones' remains?
repatriating remains affect the
grieving family?

\section{Comments}

Dealing with grief at the death of a fellow congregant is always a very difficult moment, given that most congregants, especially the close relatives, will be looking for guidance and leadership for most of the procedures and processes.

As an example, we recently lost a congregant, who just collapsed in her house and was found dead the following morning. It was required that identification be made, but none of her close friends were able and willing to do it because they were too scared. It required a very strong church member to assist. It also required that the church leaders notify her close relatives and family in Zimbabwe. It is very hard to deliver such sad news telephonically, as you cannot know how the recipient of the news will react. The church leadership is then required to mobilise the congregation to support the family in every way possible to facilitate the necessary procedures, which include: a meeting or mobilise the congregation to support the family in every way possible to facilitate the necessary procedures, which include: a meeting or
gathering place for bereavement, checking on and securing the property and belongings of the deceased and looking after the children who have been left behind.

The process of repatriating a body can only be facilitated by a funeral parlour. The first step, therefore, is to find the best service being offered, depending on affordability.

The duties of the funeral parlour include the following:

(1) Processing the necessary paperwork or permits - identification and verification of the deceased with both the local Home Affairs office and the foreign country's embassy.

(2) Preparing the body, which involves embalming to delay decomposition, according to the required health standards and issuing a certificate of death.

(3) Providing a visitation area for viewing and checking the body preparation.

(4) Transporting the remains, if their price quote has been accepted.

The process of repatriating remains affects the grieving family in two main ways:

(1) Availability: Family members have to be available for any requirements to process and prepare the body - to provide identity documents, clothing and cosmetics; to sign documents as next of kin; to be available to help coordinating the gatherings and updating friends and relatives on the progress.

(2) Financial: Family members have to make the decision on which funeral parlour to use for the body preparation, depending on affordability. Family members have to choose a package they can afford, as quoted by the service provider.

From the financial perspective, it is basically a matter of having two funerals, as there are gatherings and errands locally for the processes and procedures, and the same will be happening on the other side. Family members in the foreign country have to engage a funeral parlour as well to finish up the burial, unless a price has been agreed for the one service provider to do everything.

The body preparation and transportation may cost as little as R15 000.00. It can be cheaper if members provide their own transport, but the The body preparation and transportation may cost as little as R15 000.00 . It can be cheap
services of a funeral parlour will still be required at the final destination of the deceased.

I would classify this relationship as presenting two types of challenges:

(1) Availability: Usually most Zimbabwean expatriates living in South Africa do not have many family members or relatives available.Their family is therefore the church. The burden falls on one person or the few members available here. If employed, you require 2 weeks off from work, which may be a big challenge with your employer or if your earnings are time based.

(2) Financial: Costs for funeral parlour, communication, transportation and food.

Two ways to help migrant families deal with this double pain:

(1) Death: The migrant family needs to be allowed to gather and receive members who are coming to help and console them. They need prayers and comfort.

(2) Repatriation: The main challenge is financial; the family may require assistance to cover the main costs that are incurred here locally, such as funeral parlour and transportation costs.

Participants $(n=10)$ were selected by looking at families who had experienced repatriation of the remains of a loved one from South Africa.

Connolly et al. (2017:2) continued to say '[c]ontacting the local national embassy, travel insurance broker and tour operator, if applicable, are important initial steps in the repatriation of the deceased traveller'. The participants were also asked another question: what is the process of repatriating a body from South Africa to Zimbabwe? The participants indicated that they were not very involved in this process, as it can only be facilitated by a registered funeral parlour.

The first step, therefore, is to find the best service available according to the financial means of the family.

It is also important to note that funeral parlours can charge any price, as there are no regulations or standardised prices. Nonetheless, the participants were willing to share the process that was run by the funeral parlours they used.

\section{The challenges of repatriation of remains}

\section{Paperwork}

The third question was centred on how the process of repatriating remains affects the grieving family. One participant said that family members have to be available for any requirements to process and prepare the body.
They also have to be available to provide identity documents, clothing and cosmetics. They have to sign documents as the next of kin. They need to be available to help in coordinating gatherings and updating friends and relatives on the progress. Availability is a challenge to most of the Zimbabweans in South Africa.

The process of repatriation of remains involves not only the members of the family who are in South Africa but also those in their native land. When the relatives in Zimbabwe wait, family members in South Africa try their best to make sure that the process advances smoothly and the necessary documentation is processed in good time. The paperwork involved in the process of repatriating remains is a long one; it usually takes a week and includes the burial order, notice of death, post-mortem report, death certificate, embalming certificate, non-infectious disease letter and a permit to repatriate from the Department of Home Affairs in South Africa. A clearance letter also needs to be obtained from the Zimbabwean consulate. The South African government has been lenient in cases where an undocumented person dies, but a documented family member must complete the paperwork. A family member must do this paperwork while struggling with the fact that the one they loved is no more. The family member is expected to be strong and face the challenges involved in processing all the paperwork in order for the body to be finally repatriated back to Zimbabwe. Most of the time, such a huge responsibility requires a mature 
family member who can deal with both the pain of death and the process of repatriation of the remains.

Given the discussion between the interviewer and the participants, it is clear that repatriating remains is a challenging process, especially the paperwork involved in the process. The process is difficult for both the individual and their family. Individuals and churches who do not cope with this process actually stand at a risk of losing their jobs, if they have contractual obligations. Most of the time, both the church and the individual are not prepared for the process of repatriation of remains. Thus, when the day of death arrives, they have culture shock and do not know what do to. This is because the process of repatriating remains can become a very traumatic experience for the family and church members. At the end, the process imposes suffering and pain on others. This calls for a different approach to doing mission among the wounded. This process should not be only the responsibility of the individual and the church; companies that employ foreign nationals should rethink the way they take care of their employees, especially as it relates to funeral policies and so on. Lack of such mediation by families, churches and companies results in chaos when it comes to the process of repatriating remains (Sánchez Vidal et al. 2008:1683-1702).

\section{Finances}

The fourth question regards the relationship between mourning and the pain of repatriation. The immediate answer involves the financial implications. Hence, the repatriating funeral parlour has emerged, a specific niche in the 'death industry', which according to Nunez and Wheeler (2012:219) has emerged from the need to return deceased migrants home and offer services primarily to African migrants or their families. In this kind of funeral parlour, body preparation and transportation may cost a minimum of R15 000.00. It can be cheaper if members provide their own transport, but the services of a funeral parlour will still be required at the final destination of the deceased. Thus, repatriating a body from South Africa to Zimbabwe is expensive. Although some families who cannot raise enough money hold the funeral in South Africa, many families still insist on taking their loved ones back home. There are funeral insurance policies, but not everyone takes one out. Some of the funeral insurance companies that specialise in repatriation of remains for Zimbabweans include Doves, which has the Zimba-Mzansi funeral plan and the Zororo Phumulani division, as well as Moonlight Funeral Assurance and Services and the MFS Insurance funeral cover. When repatriated by air, an R6000 tax has to be paid on top of this at the airport to the Zimbabwe Revenue Authority, and a funeral company should be available to collect the body. Another option is to send the body by road to Johannesburg and then with Air Zimbabwe. If the person is to be buried outside of Harare, there is that additional transport cost.

The costs of repatriation also depend on how many members wish to accompany the body during transportation. Thus, these processes make body repatriation a big business these days, especially between South Africa and Zimbabwe. Costs can tally well into the thousands for body transportation services, with additional options like offering a small bus to bring relatives back to Zimbabwe with the body. Thus, the price of R15 000 can increase if more relatives are added to the list of those accompanying the body. It can therefore amount to about R23 000 to R25 000. These costs also depend on the location from which the deceased is to be taken. For example, it costs more to transport a body to Zimbabwe from Cape Town than from Durban or Johannesburg. These costs are too much for individuals and for their families. They are also costly given the economic challenges in South Africa and Zimbabwe. However, in the midst of these challenges, Zimbabweans in South Africa still insist on repatriating the bodies of their loved ones.

The main challenge is that even when members take out funeral policies, sometimes they are not enough to cover the expenses of repatriation and the funeral to be conducted back at home in Zimbabwe. The funeral itself is a costly exercise, given the fact that for the whole week they have to cook for visitors until the day of burial. Therefore, even if members take out funeral policies, they are not sufficient at times to cover all these costs. If a specific member wants to have a funeral policy that takes care of everything, they equally have to pay a fortune on a monthly basis towards such a policy. Thus, at times, Zimbabweans have to hire a South African funeral insurance company that they normally pay cash to compensate for gaps created by their own funeral policies. Thus, the South African funeral policy will cover the logistics in South Africa, then at the border responsibility will be transferred to a Zimbabwean funeral policy. In this way, the burden of this massive process is shared between the two countries. However, the South African insurance companies can be equally expensive for Zimbabweans.

\section{Dealing with the double pain of death and repatriation of remains}

The last interview question focussed on how to help migrant families deal with the double pain of death and repatriation of remains. Regarding death, one participant said that the migrant family needs to be allowed to gather and receive members who are coming to help and console them. They need prayers and comfort. Regarding repatriation, another participant said that because the main challenge is financial, they need assistance to cover the main costs that are incurred here locally, that is, funeral parlour and transportation costs. However, regarding the financial aspect, one participant highlighted that taking the decision on which funeral parlour to use for the body preparation, depending on the affordability, is pivotal. Therefore, family members have to choose the package they can afford as quoted by the service provider. Another participant said that it is important to have financial viability for gatherings and other running costs in South Africa. Financial viability is also needed for the 
processes and procedures, and the same will be happening on the other side. Family members in Zimbabwe have to engage a funeral parlour as well to finish the burial, unless a quotation has been agreed for one service provider to do everything.

The challenges of death and repatriating remains also call on Zimbabweans in South Africa to organise themselves to help each other make ends meet. In the words of Ahaddour, Van den Branden and Broeckaert (2019):

$[A]$ deceased who did not have a repatriation insurance would be helped out by the community through donations via social media (e.g. Facebook) to guarantee the deceased a dignified burial, as this is a collective duty. (p. 48)

Fellow Zimbabweans can support others, and this does not necessarily involve money; such help can be rendered in terms of organisation, paperwork and other arrangements. According to Nesteruk (2018):

$[B]$ eing with their loved ones and participating in rituals associated with death, such as making funeral preparations, sharing meals, praying, and attending services, provides them with a sense of belonging and comfort. (p. 1020)

To deal with repatriation of remains in the future, it is high time to form groups that will faithfully contribute money on a monthly basis or as crises arise, committing to distribute such monies equally among the members.

Zimbabweans in South Africa can help each other by setting up accounts that can assist members to repatriate and bury their loved ones. In the form of any organisation with the proper structure, members can elect a board with a chairperson, secretary and treasurer who will manage such an organisation. This kind of organisation can assist with burdens and administration of the process of repatriating remains for Zimbabweans living in South Africa, as repatriation is important for many Zimbabwean families, who believe that relatives must be buried in their homeland. However, as more Zimbabweans build lives outside their native country, repatriation of remains and the associated costs need creative solutions.

Those who insist on repatriation of their remains should properly plan. According to Ahaddour et al. (2019), a good repatriation should be understood as having:

$[A] \mathrm{n}$ insurance, a speedy handling of the administration (e.g. documents, tickets) and burial (e.g. washing the dead, taking care of a coffin and transportation to the morgue, airport and cemetery). (p. 48)

Knowing the difficulties of repatriation of remains and preparation can go a long way to addressing these difficulties prior to the repatriation process. Meaning, members do not have to wait until death comes but can actually plan ahead of time to make sure that the day death comes they are ready for the process of repatriation. The aspects of preparedness for repatriation, cultural identity change and attributions of causality on the repatriation experience of the individual returning home from South Africa to Zimbabwe should not be left to those who are still alive; rather, the individual should take care of these aspects personally.

A successful repatriation process can be attained when, upon arrival in South Africa, individuals think not only about the present but also the future, as to where they want to be buried when they die. This might relate to gaining access to a suitable job upon arrival in South Africa and having a proper financial plan. Access to a suitable job requires a match between a person's expectations and their actual willingness and capacity to meet those expectations. It might also involve the type of qualifications an individual holds in their career (Hyder et al. 2007:264-281).

\section{Embracing alternative burial protocol}

Alternatively, Zimbabweans living in South Africa might have to rethink the question: where is home? As Mashau (2019:2) calls on us 'To see the world as a common home that should be shared by all and for their well-being'. Maybe home could be redefined, not only in terms of where one was born but also in terms of where one lives with one's immediate family. Other than the cultural reason given by participants in previous sections, individuals need to ask themselves a bold question: What is wrong with being buried in a foreign land? After all, what is a foreign land, given the fact that many Zimbabweans have found a home on South African soil and have actually established families in South Africa? Some Zimbabweans have married South African women or men.

Others have established businesses that have created jobs for both Zimbabweans and South Africans.

Therefore, it can be reiterated, where is home for such individuals? Thus, it might be ideal given the economic challenges to opt for being buried in South Africa. The little money that a member has accumulated over the years while living in South Africa can go a long way towards assisting the family members who are still alive, especially the children of the deceased. The money can help families back in Zimbabwe who are going through economic hardships. Moreover, in the study that Ahaddour et al. (2019:42) conducted, the participants explained that God created the earth, and therefore all ground is the same. The participants expressed the belief that the deceased should be buried where God takes away the soul. In this respect, a few middle-aged participants stated that it actually does not matter where you are buried, given the fact that it is the situation of the soul in the afterlife that counts. 


\section{Rethinking cremation}

One of the ways to deal with the double pain of death and repatriation of remains is for all Africans, not only Zimbabweans, to rethink their perception on cremation. Cremation, according to Masango (2006):

$[R]$ epresents a means of disposing the remains and establishing a means of focus for remembering their deceased loved one. It can also serve as a means for recognizing the transition from body presence to body absence. (p. 1031)

However, most Africans are negative towards cremation because they are used to burying the actual body. Nonetheless, cremation can save costs because it will be cheaper to move the ashes of the dead person than to move their whole body. Another advantage of cremation is that it simplifies the funeral process, which can be very long in an African context. The fact is that in addition to moving the body back to their country of origin, there are other costs that relate to the processes leading to the final burial. Cremation can make these processes short, as family members do not have to wait for transport of the dead body. Cremation can shorten the paperwork needed to finalise the moving of the remains of the deceased back to their country of origin.

The other advantage is that cremation is not particular about the place of burial, which is normally the graveyard.

The ashes can be laid to rest in a garden at home or in the garden on the church premises. This also opens the possibility of laying the ashes to rest in the country where the deceased died because the logistics or the costs are less. The final advantage is that the remains can be laid to rest on any day of the week. The most important thing is that the family will still mourn their loved one; it does not change the way they feel about their lost family member. They still can pay their last respects in a dignified way. The respect does not change because they have cremated the body, as long as there is a service of committal. According to Masango (2006), such a service:

$[E]$ specially when the ashes are placed in a niche, buried in a garden of remembrance, or are interred, reinforces the recollection process, again remembering with respect and reflecting with respect and remembrance on the way in which the past relationship is [sic] came to an end. (p. 1031)

\section{Mission to the wounded in the light of death and repatriation of remains}

The challenges of death and repatriation of the remains mean that mission among the wounded cannot be carried out as it has been before. We need to answer an important question: what is the meaning of ministering to wounded people in a specific setting (Knoetze 2017:1)? Mission in this context would not only be understood theoretically but as being there for the wounded community (Knoetze 2017:2). It is also important to assess how wounded people are able to minister to others while in pain. Given their trauma, missiologists need to provide solutions for how such people can continue to serve the God in their situations. The reason for this assertion is that God is involved in the wounds of the people. According to Exodus 3:7, God knows the pains of his people.

Therefore, the wounded should never be perceived as people who are outcast and standing outside the will and purpose of God's mission for his people. Mission to the wounded draws a parallel between the mission of God and wounded people in the sense that God is concerned with what people are going through in their lives (Knoetze 2017:3). God wishes to see healing for those who are going through trauma.

Therefore, anyone involved in mission is called to stand in solidarity with people undergoing the same pain. The mission practitioner or even missiologist should not shy away from the daily sufferings of the people of God. Anyone involved in the mission of God who sees the injustices of the people cannot ignore them, because the same pains are the concern of God the Almighty, who is on the side of the wounded. Therefore, the concern of the participants in the mission of God is pivotal in mission to the wounded (Mashau 2018:139). The role of the Holy Spirit is also important in giving power to those who desire to take part in healing the wounded (Niemandt 2015:90). The work of the Holy Spirit will grant healing to the wounded and bring restoration to their lives. All the world needs to know is that God is still in charge even as the world receives many wounds. God has vowed to save the crying world because of his unfailing love in the midst of many atrocities. Therefore, mission to the wounded has the promise of the goodness of God happening in the midst of wounds (Molale 2018:106).

Mission to the wounded calls on missiologists and practitioners of faith to rethink and reimagine mission among the wounded. In the words of the conveners of the International Association for Mission Studies (IAMS) 2019 conference a mission to the wounded requires 'new locating and refiguring: creating resilience in those who carry wounds, pursuing spaces of religious freedom and engaging in deep solidarity, transformation and renewal'

In this kind of renewal, Dysvik and Furnes (2010:163) suggested, '[s]upport to people who suffer grief caused by death or chronic pain, should focus on grief as a specific type of experience taking a phenomenological perspective'. In the context of this article, grief is caused not only by death but also by the processes of repatriation that involve high costs. The wounded in this instance are not only the emotionally wounded but also the financially challenged individuals who cannot afford to transport the bodies of their loved ones from South Africa to Zimbabwe.

Mission to the wounded means that, following Christ and taking up the cross as presented to Christians, suffering and death cannot be the only remedy given to the wounded. There is also a need to lend a hand in terms of the financial support to be offered to the members of the deceased's family. 
This means that the preacher cannot just visit the family to preach the good news in terms of what Christ has done on the cross but needs to also encourage church members to support those going through the double pain. Yes, it is true that followers of Christ need to follow the example of Christ in suffering and dying with him, being buried with him and resurrected with him.

However, this is not enough. The same follower of Christ in his or her vulnerability, experiencing death and the challenges of repatriation of their loved one's remains, should not only be comforted with words but be given assistance as well. The redemptive work of Christ on the cross of Calvary should not be used as an excuse for not taking care of one another as members of the Christian faith. Thus, the follower of Christ already knows about the cross but needs comfort in a more practical way (Noonan 1998:387).

Nonetheless, members can find comfort in knowing that Jesus has overcome death. The prophet Isaiah 25:8 already prophesied that Christ would swallow up death in victory and God would wipe the tears from the faces of all the people. The other promise is that the shame of the people on earth shall be taken away with the victory of Christ over death. Thus, the coming of Christ according to Isaiah not only presents salvation for the people but victory over death and the promise of a shameless life. Thus, although followers of Christ experience death, the promise is that death now has no power over them. In Hosea 13:14, speaking through the mouth of the prophet, God promised to redeem people from the power of the grave. God also promised to ransom his people from the power of death itself. God declared that both grave and death would be destroyed. Thus, as the grave could not hold Christ for more than 3 days, in a similar way, the grave has no power over the followers of Christ. This does not mean that people will not die in the present, rather that death has no permanent hold over their lives.

Thus, death has no power over followers of Christ. Jesus will reign until all his enemies are found under his feet. Death and the grave no longer have power over Christ (1 Cor 15:55). In addition, one of the enemies found under the feet of Jesus is death. This is because God himself has put everything under the feet of Jesus Christ, including death. Thus, it must be understood that everything is under the feet of Christ except for the one who gave him the authority, that is, God the father (1 Cor 15:25-27). The victory of Christ over death and its power actually marks the beginning of a life of grace. To illustrate the victory of Christ over death, John the revelator says that the sea will give up its dead and death and Hades will give up their dead ( $\operatorname{Rv} 20: 13)$. In addition, both death and Hades will be thrown into the lake of fire in what is called the second death ( $R v$ 2014). Moreover, after the second death, the promise is that there will be no more death or pain inflicted upon those who will spend eternity with Christ (Rv 21:4).

Death should not be seen as the end of life but the beginning of eternal life. Anyone who views death as the final arbiter and the final destination will be discouraged when it happens, but those who view it as a door to eternal life will find comfort in Christ. Although the natural followers of Christ cannot have power over physical death, they do have power over spiritual death. Moreover, those who believe that after death they have the opportunity for eternal life cannot be discouraged and will not lose their faith. They know that there is a God in heaven, who is above death and controls everything in heaven and on earth. In the words of Marrone (1999:495-519), ‘[t]he belief in an afterlife may be the most common religion-based assimilation strategy observed in individuals dealing with loss'. Therefore, the death of Christ is the centre of Christian faith because according to Loewald (2007):

$[H]$ e is not only the ultimate love object which the believer loses as an external object and regains by identification with Him as an ego ideal, $\mathrm{He}$ is, in His passion and sacrificial death, the exemplification of complete internalization and sublimation of all earthly relationships and needs. (pp. 1113-1133)

Finally, death should not be feared by people, including African people. Death should not be feared to a level where African people worship death and/or the dead. To fear that when one is not buried at home something wrong will happen is actually the fear of death and the dead. Therefore, missiologists must convince the African people that there is no relationship between the dead and the living. When a person passes on, they cannot control those who are still alive. On the contrary, the biggest tragedy is spiritual death, when people fail to reconcile with their master because of their sin. This means that the spirit of a person is of greater importance than their body.

Therefore, instead of fearing death, people should be more concerned about where their spirits are going after that death, rather than where they should be buried.

\section{Conclusion}

Death is painful and inevitable, but death should not be allowed to take over the emotions because Christ has defeated death. In addition, there is hope after death. Thus, death should not be seen as the final destination in this life, but as a door to eternal life. The current pain of death and losing a loved one should not deter people from their walking with God. Death should not be allowed to take away the faith of those who are in the Christian community, but should rather strengthen their faith, knowing that God is still in charge. When it comes to death and the challenges of repatriation of remains, which require a lot of effort and financial strength, the matter makes sense in terms of cultural norms. However, when considering the economic hardships, it may be better to be buried in the country to which a Zimbabwean national migrated during his or her life. This means that there is a need to redefine 'home' to refer to where one is living with one's close or immediate family and not necessarily where one was born. For families that can afford repatriation of remains, there is a need for a proper plan that may involve policies and other 
financial aspects. Lastly, there is a great need to rethink cremation, as it can save costs as opposed to repatriation of the actual body.

\section{Acknowledgements}

The author thanks the Department of Christian Spirituality, Church History and Missiology for the support provided in conducting this research.

\section{Competing interests}

The author declares that he has no competing interests.

\section{Author's contributions}

M.S.K. is the sole author of this article.

\section{Ethical consideration}

The ethical clearance was issued by the University of South Africa, College of Human Sciences Research Ethics Review Committee.

\section{Funding information}

This study was financially supported by the University of South Africa

\section{Data availability statement}

Data sharing is not applicable to this article as no new data were created or analysed in this study.

\section{Disclaimer}

The views and opinions expressed in this article are those of the author and do not necessarily reflect the official policy or position of any affiliated agency of the author.

\section{References}

Ahaddour, C., Van den Branden, S. \& Broeckaert, B., 2019, "'God's land is vast". Attitudes and practices of Moroccan Muslims regarding burial and repatriation of the deceased', Mortality 24(1), 32-60. https://doi.org/10.1080/13576275.2017. 1413543

Connolly, R., Prendiville, R., Cusack, D. \& Flaherty, G., 2017, 'Repatriation of human remains following death in international travellers', Journal of Travel Medicine 24(2), 1-6. https://doi.org/10.1093/jtm/taw082
Dysvik, E. \& Furnes, B., 2010, 'Dealing with grief related to loss by death and chronic pain: Suggestions for practice. Part 2', Patient Preference and Adherence 4(1), 135-163. https://doi.org/10.2147/PPA.S10582

Fontein, J., 2009, 'The politics of the dead: Living heritage, bones and commemoration in Zimbabwe', ASA Online 1(2), 1-27, viewed n.d., from https://www.theasa.org/ publications/asaonline/articles/asaonline_0102.shtml.

Félix, A., 2011, 'Posthumous transnationalism: Postmortem repatriation from the United States to México', Latin American Research Review 46(3), 157-179. https://doi.org/10.1353/lar.2011.0046

Hyder, A.S. \& Lövblad, M., 2007, 'The repatriation process-A realistic approach', Career Development International 12(3), 264-281 https://doi.org/10.1108/ 13620430710745890

IAMS 2019, call for paper, viewed 01 February 2019, from https://www.steyler.eu/ missionswissenschaft/IAMS/Call_for_Papers_191118.pdf.

Kgatle, M.S., 2018, 'Globalisation of missions: An exegesis on the Great Commission (Mt 28:18-20)', In die Skriflig 52(1), a2346. https://doi.org/10.4102/ids. v52i1.2346

Kgatle, M.S., 2019, 'Missiology as social justice. A contextual reading of the mission of Christ in Luke 4: 16-19', Missionalia 47(1), 58-71. https://doi.org/10. 7832/47-1-297

Knoetze, J.J., 2017, 'A long walk to obedience: Missiology and mission under scrutiny (1910-2010)', In die Skriflig 51(2), 1-7. https://doi.org/10.4102/ids.v51i2.2192

Kritzinger, J.N.J., 2013, Tutorial letter for the research proposal module in the structured Master of Theology in Missiology, University of South Africa, Pretoria.

Loewald, H.W., 2007, 'Internalization, separation, mourning, and the superego', The Psychoanalytic Quarterly 76(4), 1113-1133. https://doi.org/10.1002/j.21674086.2007.tb00296.x

Makina, D., 2012, 'Determinants of return migration intentions: Evidence from Zimbabwean migrants living in South Africa', Development Southern Africa 29(3), 365-378. https://doi.org/10.1080/0376835X.2012.706034

Marrone, R., 1999 'Dying, mourning, and spirituality: A psychological perspective', Death Studies 23(6), 495-519. https://doi.org/10.1080/074811899200858

Masango, M., 2006, 'Interment of ashes: Cremation service', HTS: Theological Studies 62(3), 1029-1039. https://doi.org/10.4102/hts.v62i3.386

Mashau, T.D., 2018 'Standing where God stands. JNJ Kritzinger as an encountering missionary and missiologist', Missionalia 46(1), 131-145. https://doi.org/ $10.7832 / 46-1-278$

Mashau, T.D., 2019, 'Foreigners go home! Re-imagining ubuntology and the agency of faith communities in addressing the migration crisis in the City of Tshwane', HTS Teologiese Studies/Theological Studies 75(4), a5595. https://doi.org/10.4102/hts. v75i4.5595

Molale, M.S., 2018, 'Missio Dei: An ecclesiology of healing and reconciliation in the Methodist Church of Southern Africa in post-1994 South Africa', PhD thesis, North-West University, Potchefstroom

Nesteruk, O., 2018, 'Immigrants coping with transnational deaths and bereavement: The influence of migratory loss and anticipatory grief', Family Process 57(4), 1012-1028. https://doi.org/10.1111/famp.12336

Niemandt, C.J.P., 2015, 'Together towards new life for missiology? Mission and missiology in the light of the World Council of Churches 2013 policy statement', Acta Theologica 35(2), 82-103. https://doi.org/10.4314/actat.v35i2.6

Noonan, Jr., J.T., 1998, 'Dealing with death', Notre Dame JL Ethics \& Pub. Pol'y $12(1), 387$.

Nunez, L. \& Wheeler, B., 2012, 'Chronicles of death out of place: Management of migrant death in Johannesburg', African Studies 71(2), 212-233. https://doi.org/ $10.1080 / 00020184.2012 .702966$

Rowles, G.D. \& Comeaux, M.L., 1987, 'A final journey: Post-death removal of human remains', Tijdschrift voor economische en sociale geografie 78(2), 114-124. https://doi.org/10.1111/j.1467-9663.1987.tb00571.x

Sánchez Vidal, M.E., Sanz Valle, R. \& Barba Aragón, M.I., 2008, 'International workers' satisfaction with the expatriation process', The International Journal of Human Resource Management 19(9), 1683-1702. https://doi.org/10.1080/0958519080 2295256 